\title{
ВІК ПАЦІЄНТОК ЯК ОДИН ІЗ ФАКТОРІВ РИЗИКУ НЕВДАЛИХ СПРОБ У ЦИКЛАХ ЕКСТРАКОРПОРАЛЬНОГО ЗАПЛІДНЕННЯ (АНАЛІТИЧНИЙ ОГЛЯД ЛІТЕРАТУРИ)
}

\author{
ДВНЗ «Тернопільський державний медичний університет \\ імені І.Я. Горбачевського МОЗ України», м. Тернопіль, Україна \\ Медичний центр «Клініка професора С. Хміля», м. Тернопіль, Україна
}

\begin{abstract}
Мета: проаналізувати джерела наукової літератури щодо впливу віку пацієнтки на результати запліднення in vitro.
Матеріали і методи. У дослідженні застосовано бібліосемантичний метод - проаналізовано 35 джерел наукової літератури.

Результати. В основі позитивного результату програм допоміжних репродуктивних технологій лежить своєчасна діагностика безпліддя подружньої пари, а також застосування правильної тактики лікування. Алгоритм лікування пацієнток старшого репродуктивного віку потребує комплексного підходу, оскільки дуже часто причиною безпліддя $€$ низка взаємопов'язаних фракторів на рівні фрункціонування окремих систем організму, також пацієнтки даної групи мають підвищений ризик розвитку анеуплоїдних ембріонів та переривань вагітності на ранніх термінах.

Висновки. Отримані в ході досліджень результати можуть бути враховані при виборі тактики лікування пацієнток старшого репродуктивного віку для отримання позитивних результатів у програмах допоміжних репродуктивних технологій.
\end{abstract}

КЛЮЧОВІ СЛОВА: жінки старшого репродуктивного віку; ооцити; екстракорпоральне запліднення; анеуплоїдні ембріони.

Тенденції соціально-економічного розвитку сучасного суспільства за останні десятиліття зазнали значних змін. Чинне місце сьогодні займають освіта, кар'єра, фрінансова незалежність. Питання створення сім'ї та материнства інколи відкладають до того часу, коли зачати дитину для подружжя власними силами стає вкрай важко. 3 віком спостерігають погіршення стану соматичного здоров'я та зниження репродуктивної фрункції. Важливим це питання $\epsilon$ для жінок старшого репродуктивного віку, оскільки виснаження овуляторного резерву призводить до зниження імовірності народження власних дітей [1, 3].

Мета: проаналізувати джерела наукової літератури щодо впливу віку пацієнтки на результати запліднення in vitro.

Матеріали і методи. У дослідженні застосовано бібліосемантичний метод - проаналізовано 35 джерел наукової літератури.

Результати дослідження та їх обговорення. Репродуктивний період, тобто той вік, в якому жінка здатна до дітонародження, визначають індивідуально, цей період починається 3 появою першої менструації і завершується менопаузою. Більшість жінок досягає менопаузи до 50 років, але біологічна фертильність починає знижуватися за 10-12 років до цього етапу. Сучасні жінки відкладають реалізацію своєї репродуктивної фрункції

(С С.В. Хміль, І.В. Корда, Р.П. Микула, М.С. Хміль, 2017 на більш пізній термін. Середній вік жінок, котрі звертаються в центри планування сім'ї з приводу безпліддя, за останні роки істотно зріс [2, 5].

На сьогодні багато досліджень присвячені детермінації фракторів ризику невдалих спроб у циклах екстракорпорального запліднення (ЕКЗ), серед них вік жінки [1]. Науковцями з університету Барселони [13] проведено масштабне дослідження. Аналіз результатів 947 природніх циклів запліднення in vitro, що проводили в одному центрі в період з січня 2010 р. до грудня 2014 р. серед трьох вікових груп (35 років, 36-39 років та більше 40 років), показують, що відсоток вагітності на цикл був достовірно меншим у старшій віковій групі пацієнток (11,4 \% , 11,6 \% проти 5,9 \%). Крім того, різниця спостерігалась і у відсотках викиднів $(7,7 \%, 34,4 \%$ проти $50 \%)$ та показників прогресуючої вагітності (10,6 \%, 7,6 \% проти 3,0 \%). Регресійний аналіз показав, що вік пацієнток був єдиною змінною, яка мала вплив на імовірність настання вагітності у циклах запліднення in vitro.

За результатами досліджень [31], що проводили в одному із медичних центрів Японії в період 3 2007 до 2010 рр. серед пацієнток, яким застосовували лікування методами ДРТ, встановлено тенденцію до зменшення частоти настання вагітності на перенесення ембріона та збільшення частоти викиднів. Ці показники суттєво корелювали з віком матері та призводили до дуже низького рівня 
народжуваності у жінок старшого репродуктивного віку. Аналогічна ситуація щодо зниження відсотка живонародження з віком матері була зареєстрована в одній з клінік США. Відсоток живонароджених у період лікування становив 41,5 \% у жінок молодше 35 років, у жінок віком 35-37 років - 31,9\%, в жінок віком 38-40 років - 22,1 \%, у жінок віком 40 років - 12,4 \%, 41-42 роки - $5 \%$, у жінок віком 43-44 роки - $1 \%$ [6, 7, 9]. Молекулярно-генетичний аналіз батьківських маркерів абортативного матеріалу встановив, що більшість анеуплоїдів має жіноче походження [29].

Фізіологічний процес поступового згасання функції яєчників - одна з основних перешкод на шляху ефрективності програм ЕКЗ. Процес репродуктивного старіння у жінок відбувається внаслідок зменшення як кількості, так і якості ооцитів. Цей фрактор зниження фрертильності має вирішальне значення для вдалого запліднення і подальшого розвитку ембріона та, в майбутньому, для народження здорових дітей. Часті невдалі спроби ЕКЗ у пацієнток пізнього репродуктивного віку спонукають до використання донорських гамет, а бажання мати власних, генетично споріднених дітей нівелює з кожною наступною невдалою спробою. Саме тому важливим залишається вивчення механізму змін в яйцеклітинах, які відбуваються з віком, та розробка терапевтичних підходів, з метою народження власного здорового потомства [34].

Розробка методики запліднення in vitro та її наступне широке застосування в клінічній практиці 3 метою подолання безпліддя дали можливість спостерігати за етапами доімплантаційного ембріогенезу людини [4]. Якість яйцеклітин, тобто їх генетичну зрілість та правильну геномну організацію, не можна охарактеризувати, спираючись лише на морфометричну оцінку перед процедурою запліднення in vitro. Наявність багатьох хромосомних аномалій далеко не завжди позначається на фенотипі жіночих гамет і отриманих ембріонів, тобто не дозволяє виявляти їх візуально. На практиці це призводить до того, що в програмі ЕКЗ частина ембріонів, зазвичай високої якості, може мати генетичні дефекти. Наслідком перенесення таких ембріонів стає або їх нездатність до імплантації, або (при успішному зачатті) порушення розвитку, яке провокує репродуктивні втрати, особливо на ранніх термінах вагітності. У пацієнток пізнього репродуктивного віку, порівняно з більш молодими жінками, в програмі ЕКЗ відзначається як зменшення частоти імплантації після трансфреру, так і зростання частоти ранніх репродуктивних втрат [2].

$€$ багато фракторів, що відповідають за зниження народжуваності у жінок пізнього репродуктивного віку. Сюди відносять вікове старіння яєчників, тобто природні процеси атрезії та зниження овуляторного резерву, та чинники, пов'язані з репродуктивними органами (матка, яєчники) і загальним станом здоров'я. Основні наслідки «старіння» яйцеклітин - це низький рівень запліднення, поганий ембріональний розвиток, підвищена ймовірність спонтанного викидня та розвиток спадкових патологій плода [22, 23, 27]. Наприклад, трисомії спостерігають майже у 35 \% всіх клінічно визнаних вагітностей у жінок старше 40 років, але лише у 2-3 \% всіх клінічно визнаних вагітностей у жінок віком від 20 років [11, 16, 28, 30].

Віковозалежне виснаження яєчникового пулу може стати причиною підвищеної частоти фрормування незворотних генетичних змін ооцита. Цитогенетичні та молекулярні дослідження яйцеклітин пацієнток, які проходили лікування шляхом застосування методів ДРТ, показують, що помилки при сегрегації хромосом під час оогенезу корелюють зі зростанням материнського віку. Порушення формування веретена поділу, особливо в анасразі І, призводять до анеуплоїдії. Аномальне число хромосом є причиною більшості всіх самовільних абортів та викиднів $[17,21]$ та основною причиною вроджених вад розвитку [25]. Генетична діагностика 13, 15, 16, 18, 21, 22 хромосом першого полярного тіла ооцитів, призначених для ЕКЗ, показала, що частота виникнення хромосомно незбалансованих ембріонів у жінок віком від 35 років становить близько $20 \%$ та зростає до $60 \%$ у жінок віком 43 років і старше [15, 20, 24].

Механізми вікових змін ооцитів складні та включають каскад біохімічних і молекулярних процесів, пов'язаних із обміном речовин, геномною нестабільністю, вкороченням теломерних ділянок хромосом і зміни в сигнальних шляхах [8].

На сьогодні існує кілька гіпотез, що пояснюють причини розвитку ооцитів із генетичними порушеннями [12]. Одна із можливих причин підвищеного ризику розвитку анеуплоїдних ембріонів у жінок старшого репродуктивного віку це зниження рівня комплексу білків когезину, що задіяні в процесі розходження сестринських хроматид під час клітинного поділу. Зокрема, у жінок віком більше 40 років спостерігають знижену експресію генів REC8 та SMC1B, які кодують мейоз-специфічні білки, що відіграють одну із ключових ролей під час рекомбінації та подальшого розходження хромосом [10, 18, 33, 35].

Мітохондріальна дисорункція ще одна 3 імовірних причин виникнення хромосомних аномалій у яйцеклітинах жінок старшого репродуктивного віку. Мітохондрії $є$ важливими клітинними органелами, необхідні для синтезу аденозинтрифоссрату (АТФ), підтримки гомеостазу кальцію, окиснення жирних кислот, запуску апоптозу та ін. Мітохондрії мають власну ДНК, успадковану від матері, яка кодує білки, необхідні для окисного фросфрорилювання з подальшим синтезом АТФ. Під час другого мейотичного поділу мітохондрії в основному локалізовані навколо веретена поділу, а потім 
розсіюються у цитоплазмі. Такий розподіл дозволяє забезпечувати достатній рівень АТФ, необхідний для сегрегації хромосом і подальшої екструзії полярного тіла. Нормальне запліднення та потенціал раннього ембріонального розвитку пов'язані 3 рівнем АТФ в ооцитах людини. Встановлено [19, 32] співвідношення між вмістом мітохондріальної ДНК (мтДНК) та фертильністю: кількість копій мтДНК в ооцитах жінок знижується з віком, а накопичення мутаційних змін збільшується. Попередні дослідження показали, що клітинна концентрація мітохондріальних білків та АТФ може мати широкий вплив на експресію ядерного генома, включно епігенетичну модифікацію, транскрипцію та синтез білка. Таким чином, дисбаланс енергопостачання в ооцитах може вплинути на організацію генома майбутнього ембріона [14]. Окрім цього, ооцити 3 низьким рівнем АТФ не в змозі регулювати коливання рівня кальцію, необхідного для активації ооцита після проникнення сперматозоїда в ооплазму, як наслідок у постовуляторних не запліднених ооцитах починається процес апоптозу [26].

Пацієнтки, які звертаються в медичні центри, повинні бути поінсрормовані про те, що ризик спонтанної втрати вагітності та хромосомних аномалій зростає з віком. На сьогодні тривають дослідження присвячені вивченню молекулярних механізмів вікових змін в яйцеклітинах. Жінкам старшого репродуктивного віку рекомендовано проводити передімплантаційну генетичну діагностику з метою підвищенння частоти настання вагітності та народження здорових дітей. Одним із есрективних методів ДРТ у пацієнток пізнього репродуктивного віку це цикл запліднення in vitro з використанням донорських яйцеклітин. Частота настання вагітності при використанні таких програм висока і становить від 50 до 70 \%, що можна пояснити перенесенням більш життєздатних ембріонів на підготовлений до їх імплантації ендометрій. Слід підкреслити, що, хоча програма ЕКЗ з донорськими яйцеклітинами і характеризується більшою ефективністю порівняно з процедурою з власними яйцеклітинами, однак використання донорських програм не завжди влаштовує жінок, які прагнуть мати генетично рідну дитину.

Проблема пізнього материнства $€$ актуальною сьогодні і буде залишатися актуальною в майбутньому. Одним із шляхів вирішення цієї проблеми $€$ кріоконсервація власних яйцеклітин. Уже зараз молоді жінки, у багатьох країнах світу, які не планують вагітність на даному етапі свого життя, все частіше цікавляться можливістю кріоконсервації, тобто «заморозки» свого генетичного матеріалу. «Відкладене материнство» дає можливість стати матір'ю жінкам, без ризику втрати свого репродуктивного потенціалу з віком.

\section{Висновки}

1. Жінки старшого репродуктивного віку мають підвищений ризик репродуктивних втрат у програмах ДРТ.

2. 3 метою підвищення частоти настання вагітності та здоров'я майбутніх дітей рекомендовано проводити передімплантаційну генетичну діагностику.

3. Кріоконсервація яйцеклітин у молодому віці це один із нових підходів, що дозволяє пацієнткам пізнього репродуктивного віку народити генетично споріднену, здорову дитину.

Перспективи подальших досліджень пов'язані 3 вдосконаленням методики кріоконсервації ооцитів пацієнток у молодому віці та пошуком нових підходів щодо збереження фрертильності у жінок, які не планують народжувати дитину на даному етапі свого життя.

\section{Список літератури}

1. Амирова А. А. Факторы, влияющие на исходы ЭКО : обзор литературы / А. А. Амирова, Т. А. Назаренко, Н. Г. Мишиева // Проблемы репродукции. - 2010. - № 1. - С. 68-74.

2. Влияние возраста пациенток на частоту биологических потерь в программах ЭКО: опыт работы / Л. Д. Белоцерковцева, Л. В. Коноваленко, Е. В. Корнеева [и др.] // Проблемы репродукции. - 2008. - № 3.

3. Заліська О. М. Допоміжні репродуктивні технології у світі й Україні та їхні фрармакоекономічні аспекти / О. М. Заліська, В. С. Гуз // Раціональна фрармакотерапія. - 2011. - № 4 (21).

4. Чапля О. В. Доімплантаційний розвиток ембріонів жінок старшого репродуктивного віку / О. В. Чапля, Ю. В. Гонтар, Н. М. Білько // Вісник Дніпропетровського університету, серія біологія і медицина. - 2014. - № 5 (1). - С. 17-22.

5. Шевелева А. А. Социально-гигиенический мониторинг репродуктивного поведения, образажизни, репродуктивного и соматического здоровья подростков и молодежи, вступающей в первый брак : автореф. дисс. на соискание уч. степени доктора мед. наук / А. А. Шевелева. - М., 2000. - 41 с.

6. ACOG. Female age-related fertility decline. Committee Opinion. - 2014. March. - No. 589.

7. American college of obstetricians and gynecologists. The practice committee of the American Society for Reproductive Medicine. Famale age-Related Fertility Decline. Committee Opinion, 2014. - No. 589.

8. Are there non-invasive markers in human oocytes that can predict pregnancy outcome? / S. Kilani, S. Cooke, A. Kan, M. Chapman // Reproductive BioMedicine Online. - 2009. - Vol 18, No 5. - P. 674-680.

9. Assisted reproductive technology surveillance-United States, 2010 / S. Sunderam, D. M. Kissin, S. Crawford [et al.] // MMWR Surveill Summ. - 2013. - No. 62. - P. 1-24.

10. Cheng J.-M. Age-related loss of cohesion: Causes and effects / J.-M. Cheng, Y.-X. Liu // Int. J. Mol. Sci. - 2017. No. 18. - P. 1-14. 
11. Chiang T. Meiotic origins of maternal age-related aneuploidy / T. Chiang, R. M. Schultz, M. A. Lampson // Biol. Reprod. 2012. - No. 86. - P. 1-7.

12. Danylevska A. Causes and consequences of maternal age-related aneuploidy in oocytes: a review / A. Danylevska, J. Sebestova // Veterinarni Medicina. - 2013. - No. 58 (2). - P. 65-72.

13. Gonz I. Age, independent from ovarian reserve status, is the main prognostic factor in natural cycle in vitro fertilization / I. Gonz, A. Foruria // Fertility and Sterility. - 2016. - Vol. 106, No. 2. - P. 0015-0282.

14. Han Li. Mitochondrial dysfunction and age-related oocyte quality / Han Li, Ri Cheng Chian // Reproductive and Developmental Medicine. - 2017. - No. 25, (1, 1). - P. 45-54.

15. Hassold T. The origin of human aneuploidy: where we have been, where we are going / T. Hassold, H. Hall, P. Hunt // Human Molecular Genetics. - 2007. - No. 16. - P. R203-R208. doi:10.1093/hmg/ddm243

16. Hassold T. To err (meiotically) is human: the genesis of human aneuploidy / T. Hassold, P. Hunt // Nat. Rev. Genet. 2001. - No. 2. - P. 280-291.

17. Idiopathic recurrentmiscarriage is causedmostly by aneuploid embryos / B. Hodes-Wertz, J. Grifo, S. Ghadir [et al.] // Fertil Steril. - 2012. - No. 98. - P. 675-680.

18. Jessberger R. Age-related aneuploidy through cohesion exhaustion / R. Jessberger // EMBO Reports. - 2012. No. 13. - P. 539-546. doi:10.1038/embor.2012.54

19. Konstantinidis M. Simultaneous assessment of aneuploidy, polymorphisms, and mitochondrial DNA content in human polar bodies and embryos with the use of a novel microarray platform / M. Konstantinidis, S. Alfarawati, D. Hurd [et al.] // Fertil. Steril. - 2014. - Vol. 102 (5). - P. 1385-1392.

20. Kuliev A. Meiosis errors in over 20,000 oocytes studied in the practice of preimplantation aneuploidy testing / A. Kuliev, Z. Zlatopolsky, I. Kirillova [et al.] // Reproductive BioMedicine Online. - 2011. - No. 22. - P. 2-8.

21. Lathi R. B. Reliability of $46, \mathrm{XX}$ results on miscarriage specimens: a review of 1.222 first trimester miscarriage specimens / R. B. Lathi, S. L. Gustin, J. Keller [et al.] // Fertil. Steril. - 2014. - No. 101. - P. 178-182.

22. Meczekalski B. Fertility in women of late reproductive age: the role of serum anti-Müllerian hormone (AMH) levels in its assessment / B. Meczekalski, A. Czyzyk, M. Kunicki // J. Endocrinol. Invest. - 2016. - No. 39. - P. 1259-1265.

23. Molecular mechanism of poor embryo development in postovulatory aged oocytes: mini review / T. Takahashi, H. Igarashi, M. Amita [et al.] // Obstet. Gynaecol. Res. - 2013. - No. 39. - P. 1431-1439.

24. Multiple meiotic errors caused by predivision of chromatids in women of advanced maternal age undergoing in vitro fertilisation / A. H. Handyside, M. Montag, M. C. Magli [et al.] // J. European Journal of Human Genetics. - 2012. No. 20. - P. 742-747.

25. Nagaoka S. I. Human aneuploidy: mechanisms and new insights into an age-old problem / S. I. Nagaoka, T. J. Hassold, P. A. Hunt // Nat. Rev. Genet. - 2013. - No. 13. - P. 493-504.

26. Oocyte activation deficiency: a role for an oocyte contribution? / M. Yeste, C. Jones, S. N. Amdani [et al.] // Human Reproduction Update. - 2016. - Vol. 22, No. 1. - P. 23-47.

27. Oocyte aging: cellular and molecular changes, developmental potential and reversal possibility / Y. L. Miao, K. Kikuchi, Q. Y. Sun, H. Schatten // Hum. Reprod. Update. - 2009. - No. 15. - P. 573-585.

28. Origins and rates of aneuploidy in human blastomeres / M. Rabinowitz, A. Ryan, G. Gemelos [et al.] // Fertil. Steril. 2012. - No. 97. - P. 395-401.

29. Sherman S. L. Relationship of recombination patterns and maternal age among non-disjoined chromosomes $21 /$ S. L. Sherman, N. E. Lamb, E. Feingold // Biochem. Soc. Trans. - 2006. - No. 34. - P. 578-580.

30. Stern H. J. Preimplantation genetic diagnosis: prenatal testing for embryos finally achieving its potential / H. J. Stern // J. Clin. Med. - 2014. - No. 3. - P. 280-309.

31. Takeshima K. Efficacy, safety, and trends in assisted reproductive technology in Japan-analysis of four-year data from the national registry system / K. Takeshima, H. Saito, A. Nakaza // Assist. Reprod. Genet. - 2014. - No. 31. - P. 477-484. 32. The association of reproductive senescence with mitochondrial quantity, function, and DNA integrity in human oocytes at different stages of maturation / H. E. Duran, F. Simsek-Duran, S. C. Oehninger [et al.] // Fertil. Steril. - 2011. - No. 96 (2). P. 384-388.

33. Tsutsumi M. Age-related decrease of meiotic cohesins in human oocytes / M. Tsutsumi, R. Fujiwara, H. Nishizawa, // PLoS ONE. - 2014. - No. 9. - P. e96710.

34. Wang Y. A. Donor age is a major determinant of success of oocyte donation/recipient programme / Y. A. Wang, C. Farquhar, E. A. Sullivan // Human Reproduction. - 2012. - No. 27. - P. 118-125.

35. Wood A. J. Condensin and cohesin complexity: the expanding repertoire of functions / A. J. Wood, A. F. Severson, B. J. Meyer // Nat. Rev. Genet. - 2010. - No. 11. - P. 391-404.

\section{References}

1. Amirova, A.A., Nazarenko, T.A. \& Mishiyeva N.G. (2010). Faktory, vliyayushchiye na iskhody EKO: obzor literatury [Factors affecting the outcomes of IVF: a review of literature]. Problemy reproduktsii - Problems of reproduction, 1, 68-74 [in Russian]. 2. Belotserkovtseva, L.D., Konovalenko, L.V., Korneyeva, Ye.V., Bondareva, Ye.V. \& Shishanok, O.Yu. (2008). Vliyaniye vozrasta patsiyentok na chastotu biologicheskikh poter v programmakh EKO: opyt raboty [Influence of the age of patients on the frequency of biological losses in IVF programs: work experience]. Problemy reproduktsii - Problems of Reproduction, 3 [in Russian].

3. Zaliska, O.M. \& Huz, V.S. (2011). Dopomizhni reproduktyvni tekhnolohii u sviti y Ukraini ta yikhni farmakoekonomichni aspekty [Assistive reproductive technologies in the world and Ukraine and their pharmacoeconomic aspects]. Ratsionalna farmakoterapiia - Rational Pharmacotherapy, 4 (21) [in Ukrainian]. 
4. Chaplia, O.V., Hontar, Yu.V. \& Bilko, N.M. (2014). Doimplantatsiinyi rozvytok embrioniv zhinok starshoho reproduktyvnoho viku [Domimplantation development of embryos of women of older reproductive age]. Visn. Dnìpropetr. Unìv. Ser. Bìol. Med. - Bulletin of Dnipropetrovsk University Series Biology Medicine, 5 (1), 17-22 [in Ukrainian].

5. Sheveleva, A.A. (2000). Sotsialno-gigiyenicheskiy monitoring reproduktivnogo povedeniya, obraza zhizni, reproduktivnogo i somaticheskogo zdorovya podrostkov i molodezhi, vstupayushchey v pervyy brak [Socio-hygienic monitoring of reproductive behavior, lifestyle, reproductive and somatic health of adolescents and young people entering into their first marriage]. Extended abstract of Doctor's thesis. Moscow [in Russian].

6. (2014). ACOG. Female age-related fertility decline. Committee Opinion, 589.

7. The practice committee of the American Society for Reproductive Medicine. Famale age-Related Fertility Decline. American college of obstetricians and gynecologists, 589.

8. Kilani, S., Cooke, S., Kan, A. \& Chapman M. (2009). Are there non-invasive markers in human oocytes that can predict pregnancy outcome? Reproductive BioMedicine Online, 18, 5, 674-680.

9. Sunderam, S., Kissin, D.M., Crawford, S., Anderson, J.E., Folger, S.G., Jamieson, D.J. \& Barfield, W.D. (2013). Assisted reproductive technology surveillance-United States, 2010. MMWR Surveill Summ., 62, 1-24.

10. Cheng, J.-M. \& Liu, Y.-X. (2017). Age-related loss of cohesion: Causes and effects. Int. J. Mol. Sci., $18,1-14$.

11. Chiang, T., Schultz, R.M. \& Lampson, M.A. (2012). Meiotic origins of maternal age-related aneuploidy. Biol. Reprod., 86, 1-7. 12. Danylevska, A. \& Sebestova, J. (2013). Causes and consequences of maternal age-related aneuploidy in oocytes: a review. Veterinarni Medicina, 58 (2), 65-72.

13. Gonz, I. \& Foruria, A. (2016). Age, independent from ovarian reserve status, is the main prognostic factor in natural cycle in vitro fertilization. Fertility and Sterility, 106, 2, 0015-0282.

14. Li, H. \& Chian, R.-Ch. (2017). Mitochondrial dysfunction and age-related oocyte quality. Reproductive and Developmental Medicine, 25, 1, 1, 45-54.

15. Hassold, T., Hall, H. \& Hunt, P. (2007). The origin of human aneuploidy: where we have been, where we are going. Human Molecular Genetics, 16, R203-R208. doi:10.1093/hmg/ddm243

16. Hassold, T. \& Hunt, P. (2001). To err (meiotically) is human: the genesis of human aneuploidy. Nat. Rev. Genet., 2, $280-291$. 17. Hodes-Wertz, B., Grifo, J., Ghadir, S., Kaplan, B., Laskin, C.A., Glassner, M. (2012). Idiopathic recurrentmiscarriage is causedmostly by aneuploid embryos. Fertil. Steril., 98, 675-680.

18. Jessberger, R. (2012). Age-related aneuploidy through cohesion exhaustion. EMBO Reports, 13, 539-546. doi:10.1038/ embor.2012.54

19. Konstantinidis, M., Alfarawati, S. \& Hurd, D. (2014). Simultaneous assessment of aneuploidy, polymorphisms, and mitochondrial DNA content in human polar bodies and embryos with the use of a novel microarray platform. Fertil. Steril., 102 (5), 1385-1392.

20. Kuliev, A., Zlatopolsky, Z., Kirillova, I., Spivakova, J., Cieslak Janzen, J. (2011). Meiosis errors in over 20,000 oocytes studied in the practice of preimplantation aneuploidy testing. Reproductive BioMedicine Online, 22, 2-8.

21. Lathi, R.B., Gustin, S.L., Keller, J., Maisenbacher, M.K., Sigurjonsson, S., \& Tao, R. (2014). Reliability of $46, X X$ results on miscarriage specimens: a review of 1,222 first trimester miscarriage specimens. Fertil. Steril., 101, 178-182.

22. Meczekalski, B., Czyzyk, A. \& Kunicki, M. (2016). Fertility in women of late reproductive age: the role of serum anti-Müllerian hormone (AMH) levels in its assessment. J. Endocrinol. Invest., 39, 1259-1265.

23. Takahashi, T., Igarashi, H., Amita, M., Hara, S., Matsuo, K. \& Kurachi, H. (2013). Molecular mechanism of poor embryo development in postovulatory aged oocytes: mini review. Obstet. Gynaecol. Res., 39, 1431-1439.

24. Handyside, A.H., Montag, M., Magli, M.C., Repping, S., Harper, J., Schmutzler, A. ... Geraedts, J. (2012). Multiple meiotic errors caused by predivision of chromatids in women of advanced maternal age undergoing in vitro fertilisation. European Journal of Human Genetics, 20, 742-747.

25. Nagaoka, S.I., Hassold, T.J. \& Hunt, P.A. (2013). Human aneuploidy: mechanisms and new insights into an age-old problem. Nat. Rev. Genet., 13, 493-504.

26. Yeste, M., Jones, C., Amdani, S.N., Patel, Sh. \& Coward K. (2016). Oocyte activation deficiency: a role for an oocyte contribution? Human Reproduction Update, 22, 1, 23-47.

27. Miao, Y.L., Kikuchi, K., Sun, Q.Y. \& Schatten, H. (2009). Oocyte aging: cellular and molecular changes, developmental potential and reversal possibility. Hum. Reprod. Update, 15, 573-585.

28. Rabinowitz, M., Ryan, A., Gemelos, G., Hill, M., Baner, J. \& Cinnioglu, C. (2012). Origins and rates of aneuploidy in human blastomeres. Fertil. Steril., 97, 395-401.

29. Sherman, S.L. Lamb, N.E. \& Feingold, E. (2006). Relationship of recombination patterns and maternal age among non-disjoined chromosomes 21, Biochem. Soc. Trans., 34, 578-580.

30. Stern, H.J. (2014). Preimplantation genetic diagnosis: prenatal testing for embryos finally achieving its potential. J. Clin. Med., 3, 280-309.

31. Takeshima, K., Saito, H. \& Nakaza A. (2014). Efficacy, safety, and trends in assisted reproductive technology in Japananalysis of four-year data from the national registry system. Assist. Reprod. Genet., 31, 477-484.

32. Duran, H.E., Simsek-Duran, F. \& Oehninger, S.C. (2011). The association of reproductive senescence with mitochondrial quantity, function, and DNA integrity in human oocytes at different stages of maturation. Fertil. Steril., 96 (2), $384-388$.

33. Tsutsumi, M., Fujiwara, R., Nishizawa, H., Ito, M., Kogo, H., Inagaki, H. ... Kurahashi, H. (2014). Age-related decrease of meiotic cohesins in human oocytes. PLOS ONE, 9, e96710.

34. Wang, Y.A., Farquhar, C. \& Sullivan, E.A. (2012). Donor age is a major determinant of success of oocyte donation/ recipient programme. Human Reproduction, 27, 118-125.

35. Wood, A.J., Severson, A.F. \& Meyer, B.J. (2010). Condensin and cohesin complexity: the expanding repertoire of functions. Nat. Rev. Genet., 11, 391-404. 
ВОЗРАСТ ПАЦИЕНТОК КАК ОДИН ИЗ ФАКТОРОВ РИСКА НЕУДАЧНЫХ ПОПЫТОК В ЦИКЛАХ ЕКСТРАКОРПОРАЛЬНОГО ОПЛОДОТВОРЕНИЯ (аНаЛИТИчесКИЙ обЗОр литераТУрЫ)

С.В. Хмиль, И.В. Корда, Р.П. Мыкула, М.С. Хмиль

ГВУЗ «Тернопольский государственный медицинский университет имени И.Я. Горбачевского МЗ Украины», г. Тернополь, Украина

Медицинский центр «Клиника профессора С. Хмиля», г. Тернополь, Украина

Цель: проанализировать источники научной литературы о влиянии возраста пациентки на результаты оплодотворения in vitro.

Материалы и методы. В исследовании был применен библиосемантический метод - проанализированы 35 источников научной литературы.

Результаты. В основе положительного результата программ вспомогательных репродуктивных технологий лежит своевременная диагностика бесплодия супружеской пары, а также применение правильной тактики лечения. Алгоритм лечения пациенток старшего репродуктивного возраста требует комплексного подхода, поскольку очень часто причиной бесплодия является ряд взаимосвязанных фракторов на уровне функционирования отдельных систем организма, также пациентки данной группы имеют повышенный риск развития анеуплоидных эмбрионов и прерываний беременности на ранних сроках.

Выводы. Полученные в ходе исследований результаты должны быть использованы при выборе тактики лечения пациенток старшего репродуктивного возраста для получения положительных результатов в программах вспомогательных репродуктивных технологий.

КЛЮЧЕВЫЕ СЛОВА: женщины старшего репродуктивного возраста, ооциты, экстракорпоральное оплодотворение, анеуплоидные эмбрионы.

\author{
AGE OF PATIENTS AS ONE OF THE FACTORS OF THE RISK OF FAILED ATTEMPTS IN THE CYCLE \\ OF EXTRACORPORAL FERTILIZATION (analytical review of literature) \\ S.V. Khmil, I.V. Korda, R.P. Mykula, M.S. Khmil \\ I. Horbachevsky Ternopil State Medical University, Ternopil, Ukraine \\ Medical Center "Clinic of Professor S. Khmil", Ternopil, Ukraine
}

Purpose: to analyze the sources of scientific literature on the influence of the patient's age on the results of in vitro fertilization.

Materials and Methods. The study applied bibliosemantic method - 35 sources of scientific literature were analyzed.

Results. At the heart of the positive result of ART programs is the timely diagnosis of infertility of a married couple, as well as the application of the correct treatment tactics. The algorithm of treatment of patients of advanced maternal age requires an integrated approach, since very often the cause of infertility is a number of interrelated factors at the level of functioning of individual body systems, and patients of this group have an increased risk of developing aneuploid embryos and early pregnancy interruptions.

Conclusions. The results obtained in the course of the research should be used in choosing the tactics of treatment of patients of advanced maternal age for obtaining positive results in ART programs.

KEY WORDS: maternal age; oocytes; in vitro fertilization; aneuploid embryos.

Рукопис надійшов до редакції 05.11.2017 p.

Відомості про авторів:

Хміль Стефан Володимирович - профресор кафедри акушерства та гінекології № 1 ДВНЗ «Тернопільський державний медичний університет імені І.Я. Горбачевського МОЗ України», заслужений діяч науки і техніки України, профресор, доктор медичних наук.

Корда Інна Володимирівна - доцент кафедри акушерства та гінекології № 2 дВНЗ «Тернопільський державний медичний університет імені І.Я. Горбачевського МОЗ України», кандидат медичних наук; тел.: +38(0352) 52-38-81. Микула Руслана Петрівна - здобувач наукового ступеня кандидата біологічних наук, ембріолог медичного центру «Клініка профресора С. Хміля»; тел.: +38(097) 620-97-86.

Хміль Марія Стефанівна - асистент кафедри акушерства та гінекології № 1 ДВН3 «Тернопільський державний медичний університет імені І.Я. Горбачевського МОЗ України»; тел.: +38(067) 846-35-34. 